Instructions for authors, subscriptions and further details:

http://rise.hipatiapress.com

\title{
Collaborative Writing as Educational Research: a Deleuzian Critique
}

David Ernest Harris ${ }^{1}$

1) Plymouth Marjon University, United Kingdom

Date of publication: February $25^{\text {th }}, 2018$

Edition period: February 2018-June 2018

To cite this article: Harris, D.E. (2018). Collaborative Writing as

Educational Research: a Deleuzian Critique, International Journal of

Sociology of Education, 7(1), 24-48. doi: 10.17583/rise.2018.2881

To link this article: http://dx.doi.org/10.17583/rise.2018.2881

PLEASE SCROLL DOWN FOR ARTICLE

The terms and conditions of use are related to the Open Journal System and to Creative Commons Attribution License (CC-BY) 


\section{Collaborative Writing as Educational Research: a Deleuzian Critique}

David Ernest Harris

Plymouth Marjon University

(Received: 22 July 2017; Accepted: 2 January 2018; Published: 25 February 2018)

\section{Abstract}

This article discusses the claims made by some qualitative researchers that collaborative autoethnographic writing serves to displace sociology and other social sciences as a means to understand subjectivity. Collaborative creative writing claims to be no less valid than sociological inquiry and is less socially exclusive, and academic criticism of this approach is itself seen as only subjective. A particular project by Wyatt and Gale and others can still be exposed to 'immanent critique', however, where the philosophical resources used to support the argument (the work of Deleuze and Guattari in this case) can be explored to suggest quite different implications for subjectivity. These include discussing external social influences on creativity and collaboration, and, more generally, on subjectivity itself. Guattari's cartography of subjectification suggests that sociological inquiry, including the sociology of education, still has a major role in providing empirical examples and experiences of the processes involved, as resources for subsequent deleuzian philosophising and for effective micropolitics.

Keywords: collaborative autoethnography, Deleuze, Gale, Guattari, subjectification, Wyatt 


\section{Escritura Colaborativa como Investigación Educativa: Una Crítica Deleuziana}

David Ernest Harris

Plymouth Marjon University

(Recibido: 22 Julio 2017; Aceptado: 2 Enero 2018; Publicado: 25 Febrero 2018)

\section{Resumen}

Este artículo discute las afirmaciones hechas por algunos investigadores cualitativos de que la escritura autoetnográfica colaborativa sirve para desplazar a la sociología y otras ciencias sociales como un medio para comprender la subjetividad. La escritura creativa colaborativa afirma ser no menos válida que la investigación sociológica y es menos socialmente excluyente, y la crítica académica de este enfoque se considera solo subjetiva. Sin embargo, un proyecto particular de Wyatt y Gale y otros aún puede exponerse a la "crítica inmanente", donde los recursos filosóficos usados para apoyar el argumento (el trabajo de Deleuze y Guattari en este caso) pueden explorarse para sugerir implicaciones bastante diferentes para subjetividad. Esto incluye discutir las influencias sociales externas sobre la creatividad y la colaboración, y, de manera más general, sobre la subjetividad misma. La cartografía de subjetivización de Guattari sugiere que la investigación sociológica, incluida la sociología de la educación, todavía tiene un papel importante en la provisión de ejemplos empíricos y experiencias de los procesos involucrados, como recursos para la filosofización deleuziana posterior y para la micropolítica efectiva.

Palabras clave: autoetnografía colaborativa, Deleuze, Gale, Guattari, subjetivación, Wyatt. 
E

mpirical sociology has been criticised from a number of positions based on various kinds of linguistic stances, including Wittgenstein's linguistics, structural linguistics and conversation analysis. The common thread is that social science is redundant because its characteristic forms of research and theorising are misplaced and objectified. Ordinary language alone is perfectly capable of grasping the dynamics of social life.

One of the later developments to make this sort of argument is autoethnography. Conventional ethnography was always developed as part of the methodological resources of sociology in uncovering the subjective dimensions of collective social life, especially if it researched 'others', outside the mainstream in some way. However, there have always been problems with the methodology and with the politics of ethnography, turning on that moment when subjective accounts of social life are transformed into sociological data. It is difficult to avoid power relations to impose meaning, or what Bourdieu (2000) called 'symbolic violence', at that point. One solution is not to transform the accounts that people give of their lives in that way, to work with unmediated life histories or other entirely subjective accounts.

Postmodern philosophical critique of the claimed privilege of sociological concepts strengthened this trend. Short, Turner \& Short (2013, p. 3) say that autoethnography emerged from 'scepticism toward positivistinformed "master" or "grand" narratives, which claim objectivity, authority and researcher neutrality in the study of social and cultural life...disinterested, "objective" instruction gives way to evocative, emotionally-resonant connection'. Unlike conventional ethnographic research, which can involve subsequent coding or external theoretical interpretation, autoethnographers have developed 'new forms of subjectivist writing, which focus on the local and the particular... utilising creative written and analytical practices, including literary tropes' (2013, p. 4).

Autoethnography can offer commentary on academic discourse, usually through attempts to connect subjective accounts to theoretical issues, but still in an unmediated way, by the autoethnographers themselves. Thus personal experience of discrimination in the university might be linked to more general theoretical accounts of the formation of gender identity, as in many studies, including Gannon and Davies (2006), or attempts to see the 
transformations of subjective aspects of university life can be seen as a result of 'neoliberalism'. However, personal experience still retains its privileged position as the only kind of valid evidence of the personal effects of these policies.

There might be no way to fully reconcile autoethnographic and sociological thought. There can be collaborative forms of autoethnography as we shall see, but understanding the other is no longer understood to be a sociological problem requiring any particular method: ordinary forms of interaction will resolve the difficulties, especially if participants are prepared to disclose fully their views and their feelings to each other.

For enthusiasts, autoethnographic approaches ought increasingly to dominate research, especially of the effects of particular organisations and regimes on the subjective lives of participants, while conventional sociological research will eventually become redundant. This intention is perhaps clearest in Denzin's (2017) recent contribution to the influential Handbook of Qualitative Research edited by Denzin \& Lincoln: he invited the audience to declare that the very concept of data is now dead.

Many of the arguments can be seen developed in other contributions to that Handbook. The work of Richardson is of particular relevance to this article in influencing the particular project that is to be discussed. Richardson suggests deploying more lively writing techniques derived from creative fiction or poetry, partly to engage readers by providing details about the normal lives of authors. 'Form and content are inseparable' (Richardson 2000, p. 923): in 'postmodernism', the boundaries between ethnography, poetry and drama are blurred. Poetry especially can 'recreate lived experience and evoke emotional responses' (2000, p. 931). Social science already uses powerful metaphors. Since all these forms arise from 'creative analytic practices' they can all be considered as 'CAP ethnography' (2000, p. 929).

\section{Creative Writing in Richardson}

Richardson (2000) sees 'creative writing' as a qualitative research method, perhaps the only valid one. Writing is not just a matter of telling people about the social world, but is a form of knowing in itself, discovering 'new aspects of our topic and our relationship to it'. We should now focus on the 
creative and the analytic in autoethnographic writing to help the reader to share and 'relive the events emotionally with the writers' (2000, p. 931). Science writing is as conventional, as any other form, and scientific conventions should be rejected because ordinary speech is closer to poetry than scientific prose. No specific examples are offered to justify these substantial generalizations, however.

The rules of conventional ethnography are seen as 'arbitrary, narrow, exclusionary, distorting, and alienating' (2000, p. 939), and this seems to be supported by personal experiences of early rejection of her own work. Minorities within academia will find this new approach welcoming, and increasing access will enrich and diversify the community of qualitative researchers.

The writing should still display 'coherence, verisimilitude, and interest' (Richardson 2000, p. 931), partly because university autoethnographers have to assess student work, and this leads to a list of criteria (2000, p. 938), which includes 'substantive contribution'; 'aesthetic merit' (including whether work is 'artistically shaped and satisfying, complex and not boring'); 'reflexivity', showing an (uncritical?) awareness of the 'epistemology of postmodernism'. The list persists in a slightly different form in the latest version (Richardson \& St Pierre, 2017). There should also be personal 'impact': 'does this affect me? Emotionally? Intellectually? Does it generate new questions? Move me to write? Move me to try new research practices? Move me to action?'

Richardson (2000, p. 941) ends with some basic suggestions for developing more 'creative writing', which include developing 'attentiveness to your senses... as a bulwark against the censorious voice of science'. Autoethnographers should experiment with evocative writing in particular, for example by turning field notes into drama or a poem and exploring 'writing narratives of the self' (2000, p. 942). Some of these techniques feature in the subsequent work of Wyatt et al.

There are clearly problems with this argument, however, for example in a rather uncritical reliance on 'postmodernism' which tends to reduce all forms of writing to equivalents, regardless of intention or content. It is perfectly true that science writing can never escape completely from subjectivity, but that does not mean that it should follow the intention to 'recreate lived experiences and evoke emotional responses', unless we are to 
privilege those over other research goals, which will require justification. We are not guided in the case where other criteria might also contradict, where, say, 'personal impact' might be present despite the absence of any new discoveries about a topic.

Personal impact seems to be particularly problematic since it runs the risk of becoming arbitrary and even dogmatic or authoritarian. It must be difficult to disagree with Richardson's estimate of any personal impact on her specifically, at least without seeming to make personal criticism of her subjective reactions and judgments. This leads to a central problematic claim for the approach since it assumes that the sole source of knowledge about personal subjectivity is the person themselves, that there are no external determinants of subjectivity of which persons are unaware, no unconscious or socio-cultural elements for example, no awareness of how these might intrude on apparently purely personal knowledge or language, no role for any sociological or social philosophical analysis of these elements.

\section{External and Immanent Critique}

It is difficult to critique approaches which privilege personal subjectivity, however, since for postmodern relativists, any expert discourses claiming to identify external constraints on personal subjectivity can only be subjective themselves. Only the power of universities still preserves these privileged concepts (Gale \& Wyatt 2018).

There is no convincing reason why we should prefer, say, Bourdieu's sociological critiques of universities to Richardson's personal account: both are clearly subjective in the general sense. This abstract similarity seems sufficient to cancel any differences in content or intent. At worst, academic critique can be seen itself as a form of oppression or criticism as suggested above. Together, these two arguments can provide an almost impregnable defence, offering what Baudelot (in Bourdieu, Passeron \& St Martin 1994, pp.88--9) once called 'prophylactic relativism', designed to forestall critique altogether: students argued that since there are no right answers, any suggestion that someone has written a wrong one can only be based on a hostile personal opinion. Perhaps that is why the writers considered here are often enthusiastically supported and reassured by other creative writers and autoethnographers in the same academic network, indignantly rallying to 
defend them against unfair personal attack.

Badley (2011, pp. 483-4) noticed the difficulties in his attempt at a critical review of Gale and Wyatt (2009): the book has been 'praised as methodologically significant and pedagogically important...as beautiful, brilliant, evocative, erudite, original, profound and sensitive. A critical or nonaffirmative review may well be received as sour and curmudgeonly ...perhaps reviews should eschew any criticism that is not affirmative'. Badley proposes to proceed instead as a 'textor', someone who works on the basis that any text is 'both plural and multilogical', so that it becomes possible to analyze a 'textual score', to see how a text reveals a writer's voice.

One similar critical option is what was once called 'immanent critique' in Critical Theory. The approach works with materials suggested to be relevant by the writers themselves. Neglected implications in these materials are then unpacked to reveal problems with the central argument after all. In this case, the work of Deleuze and Guattari is cited as relevant by Richardson and St Pierre as well as Wyatt and Gale -- Richardson (Richardson \& St Pierre 2005, p. 965) refers to her own work as 'rhizomatic' and St Pierre describes Richardson as indicating a deleuzian 'line of flight' (2005, p.968). However, deleuzian work can then be discussed to suggest implications that are critical for the whole notion of personal subjectivity that informs the work. These can suggest a role for sociology and other social sciences as well.

Immanent critique does not completely demolish the case that all readings are subjective, but it shifts the ground in an important way to ask whether other readings are equally possible and, if so, how they might be compared, and what the grounds might be for preferring one. For example, a reading might be either corrigible or dogmatic, more open to critique or more defensive. Specifically, we can ask whether particular readings of Deleuze and Guattari have been selected to support the emphasis on personal subjectivity, and how alternative readings have been dealt with. If a focus on the personal does act in this defensive way, it is possible to see it as demonstrating a pathological form for Deleuze and Guattari, (for example Deleuze 1990) where subjectivity collapses into a 'black hole' incapable of forming any transversal links with other discourses or domains. 


\section{Wyatt and Gale and Collaborative Writing}

This article aims principally to examine how the work of Deleuze singly, but mostly that of Deleuze and Guattari together, has been used in support of a particular project of collaborative writing by Gale, Wyatt and others, especially in Gale \& Wyatt (2009) and Wyatt, Gale, Gannon \& Davies (2011a). The project claims to be well established in universities, to have produced important published contributions to qualitative research, influenced teacher training, and become a model for 'new and creative writing practices in the university of the future' (Wyatt \& Gale 2017, p. 3).

Richardson and St Pierre on creative writing have had a major continuing influence on this project, but there is a special place for deleuzian work in Wyatt et al.: 'we wanted to bring Deleuze's concepts to life in our collaborating bodies and our unfolding engagements with life in its specificity - and in its Being' (Wyatt, J., Gale, K., Gannon, S., Davies, B., Denzin, N., \& St. Pierre, E. 2014 , p. 3): 'We look to Deleuze for our primary ways of knowing' (Gale \& Wyatt 2009, p. 29). Their collaborative writing was continually justified by relating it to the collaborations between Deleuze and Guattari and the creative effects this produced.

The actual substance of the writings initially covered conventional autoethnographic interests in subjectivity, emotions and feelings, with the writing seen as a distinct method to access these. Perhaps the best example is Wyatt, Gale, Russell, Pelias \& Spry (2011b, p. 253): 'We offer stories of how writing touches and how it writes bodies into being and in between, returning to love and intimacy as scholarly, messy, complex methodology' . Substantial emotional labour seems to have been required to sustain this project, and it collapsed. In Gale, Pelias, Russell, Spry \& Wyatt (2013, pp. 9-10), one of the participants refers to:

the guilt associated with not doing our agreed upon task as we would have liked, with not being the people we strived to be within our group...meaning to write back with sensitivity and insight...I did not like the weight of it all. I did not like myself...Perhaps it was feeling we were not sufficiently taken up, that our writing was left hanging, ignored, or addressed in only a perfunctory manner. We felt slighted, hurt. 


\section{Harris-Collaborative Writing}

Less emotionally demanding and more abstract methodological issues are prominent in the later works.

Throughout, the writing is attributed to characters like 'Ken', 'Jonathan' and others. Despite sharing names, the characters are not to be seen as authentic representations of the authors: 'we make no argument - at allthat we are in search of "authenticity" (Wyatt \& Gale 2011, p. 494). The writings themselves are therefore best described, perhaps, as what Denzin calls 'truthful fictions' (Wyatt et al. 2014), although again this makes it difficult to assess them critically.

The contention here is that this project involves selective reading and quoting of deleuzian work, not as a sign of scholarly inadequacy compared to some 'true' account, but as a consequence of the privilege accorded to personal subjectivity. This restricts interest and leads to insufficient exploration of the arguments that surround the deleuzian concepts cited in support of the claims about collaborative writing.

\section{Reading Deleuze and Guattari Subjectively}

The interest in immediate and personal subjectivity seems to have influenced the way in which Deleuze and Guattari have been read. To refer back to Richardson, if there are no substantial differences between genres of writing, and if the main aim of good writing is to liberate emotions in the reader, it becomes possible to read deleuzian work in a particular way. Gale \& Wyatt (2009, p. 45) describe reading Deleuze \& Guattari (2004):

Sometimes I read passages that I have read a hundred times before, indulging in the poetry of the writing and finding pleasures in the unusual tropes... and, on other occasions, often quite absent-mindedly, I will lift [a book] from its resting place... open the pages at random and find myself being taken to new heights of intimacy, enjoying pleasures that I hadn't dreamed of.

This approach is contrasted with its rhetorical opposite, a 'desire to define, to express the all-embracing denotative utterance, [which] can have pre-occupying effects; the need to colonize meaning becomes obsessive' (Gale \& Wyatt 2009 , p. 3). This binary seems to exhaust the possibilities.

Other sections refer to reading deleuzian works using a technique where a 
character 'pulled out more quotes from Deleuze' (Wyatt et al. 2011a, p.43) using unspecified criteria for selection. Quotes are common throughout the work, largely from Deleuze \& Guattari (2004) at first but also from Deleuze \& Parnet (1987). It is not clear why these volumes have been chosen for particular attention, though, unless it is because these are both collaborative works.

It is impossible to justify adequately the argument here, with no room for extended textual references, but none of the quotes seem to raise problems for the basic approach. They seem to be always taken as immediately relevant to and supportive of the focus on personal subjectivity. As perhaps the clearest example, Wyatt et al. (2011a, p. 26) supply additions in square brackets to a quote from Deleuze \& Parnet (1987) which makes the character 'Deleuze' seem to contribute directly to their specific project: 'What mattered was not the points-[Ken, Bronwyn, Susanne, Jonathan]-who functioned simply as temporary, transitory and evanescent points of subjectivation - but the collection of bifurcating, divergent and muddled lines, which constituted this [writing] as a multiplicity'.

It can be seen that this quote actually follows from a discussion of how Dialogues 'aims to highlight the existence and actions of multiplicities in very different domains... [to focus on] the formations of the unconscious...literary, scientific and political formations' (1987, pp. viii-ix), which describes quite a different, explicitly philosophical, project ranging across a wide range of academic interests.

In (Gale \& Wyatt 2017, p. 25) the problem of making quotes relevant to their project on personal or interpersonal subjectivity seems to have been transcended altogether:

to 'quote' him [Deleuze] is to do disservice to him. He is already present in our words, in these bodies writing, in these material spaces, in the morning light that catches the edge of a kitchen table, as we grasp for what might be possible, what might be opened up, what might become-other, for where working at the wonder might take us.

This poetic approach seems to have led to the omission of many topics in Deleuze \& Guattari (2004). Many of the Plateaus are not mentioned, including the ones on freudian analysis, linguistic regimes, State apparatuses of capture, the novella, micropolitics, faciality and the refrain, all important 


\section{Harris - Collaborative Writing}

for discussing subjectivity and the external influences on it.

Denzin noticed the unusual focus of the Wyatt et al. readings. He had apparently studied Deleuze and Guattari in a student reading group which had emphasised the themes of capitalism and schizophrenia, and he notes that Wyatt et al. (2011a) said 'very little, if anything... about politics, madness, or capitalism' (Wyatt et al. 2014, p. 6). Denzin raises, but does not pursue, the important issue of how different readings might be compared: 'Whose genealogy shall I follow?' In the absence of any possibility of shared criteria for choice, this seems to leave only opportunism.

One possible justification for the particular approach to reading Deleuze and Guattari might be found in St Pierre (2004, p. 289) discussing a metaphor coined by Virginia Woolf, involving a dog running along a road, cited in the section on haecceity in Plateau 10 of Deleuze \& Guattari (2004, p. 290). In a much-cited phrase, for example in Wyatt and Gale (2014), St Pierre says the metaphor 'made sense to me. I got it, or, rather, I plugged it (however one makes sense of it) into my own musings about subjectivity and it worked'. 'Plugging in' in Deleuze \& Guattari (2004, pp 4-5) seems to originate in discussions of desiring machines rather than subjective individuals, however, and can be seen to imply a machinic understanding of writing: 'A book itself is a little machine... when one writes the only question is which other machine the literary machine can be plugged into, must be plugged into in order to work...Literature is an assemblage'. This machinic conception is discussed below.

Even in personal and subjective terms, much will depend on whether the metaphor leads to an exploration of deleuzian concepts or just to a moment of confirmation of existing knowledge. St Pierre herself does indeed subsequently explore the implications in a more critical and systematic direction than do Wyatt and Gale. She says their project must still retain the notion of the humanist subject, 'the intentional writer... The author' (Wyatt et al., 2014, p. 8). More generally: 'We can't just drop a Deleuzo-Guattarian concept ... which brings along with it their entire transcendental empiricism - into a study grounded in a humanist ontology' (St Pierre 2016, p. 8). 


\section{Reading Badiou Subjectively}

There is a particularly unfortunate consequence of subjective reading in this final example. In specifically academic writing, it is common to summarize the positions of others accurately and at some length, perhaps in the form of 'indirect discourse', before critiquing them. This practice is not always found in normal discourse, and can be missed if the two discourses are made abstractly equivalent. Badiou is about the only critic of Deleuze discussed in the whole project, but he is not explored (Wyatt et al. 2011a, p. 132). Badiou (2000, p.9) is quoted, offering examples of different images of Deleuze (I have abridged the actual quote):

There is an image of Deleuze as... vitalist and democratic. It is fairly commonly believed that his doctrine promotes the heterogeneous multiplicity of desires and encourages their unrestrained realization... That he preserved the rights of the body... constantly commended the Open and movement, advocating and experimentation without pre established norms... It is equally believed that he participates in modern (postmodern?) "Deconstruction"

However, the next section, beginning on the next page, is not quoted or discussed. No reason for the omission is given, but it looks as if it is only the first section that supports the interests of the collaborators. Badiou (2000, p. 10) actually goes on to reject these images, as an introduction to the rest of his book:

...let us also remind those who naively celebrate a Deleuze for whom everything is event, surprise and creation that the multiplicity of "what occurs" is but a misleading surface... All those who believe that Deleuze's remarks may be seen to encourage autonomy or the anarchizing ideal of the sovereign individual populating the Earth with the production of his/her desires are no less mistaken... [The machinic conception of desire]... strictly precludes any idea of ourselves as being, at any time, the source of what we think or do.... [and], contrary to all egalitarian and all "communitarian" norms, Deleuze's conception of thought is profoundly aristocratic.

Many other examples of selectivity might be signposted for additional 


\section{Harris-Collaborative Writing}

discussion. The writers concerned claim that their work can be understood as a 'line of flight', but the actual discussion in Deleuze and Guattari (2004) shows that lines of flight can take different forms - absolute and relative, for example. Pursuing this issue would lead to the discussion of creativity as arising from the dynamics of the multiplicity, not just in personal forms. There is also a politics of lines of flight, and how they are resisted. This would add an important 'external' dimension to purely personal efforts. It would be especially interesting to discuss the politics of their own work, which began facing considerable resistance from conventional university authorities (Gale, Speedy \&Wyatt 2010) but seems to have ended as a wellestablished academic enclave after all, strengthening, possibly, the business model of the university as a humane and creative institution offering therapy to overcome the strains of academic life.

\section{External Dimensions of Subjectivity in Creative Writing}

Continuing the immanent critique by choosing areas that Wyatt et al. pursue themselves, there is a great deal of discussion of fictional literature and some poetry in deleuzian work, but it is barely mentioned in Wyatt et al.. Discussion seems to follow a rather different project than the one suggested in Richardson. Instead of adding colour and emotional resonance to academic accounts, suitable fiction is to be read 'clinically', as a source of experience that is just as relevant for philosophy as direct communications between individuals. Deleuze (1997) has a whole set of essays showing how this can be done.

The chosen novellas in Deleuze and Guattari (2004) illustrate the most commonly available 'lines of subjectivity' in our society, for example. One prominent example of poetry cited by Deleuze and Guattari (2004), a work by Ghérasim Luca, recounts all the routine events that were taking place at the same time as the funeral of one of his friends. The discussion does not prioritise the emotions associated with bereavement, but sees the poem as demonstrating the 'haecceity', the contingent and nonsubjective conjunctions of heterogeneous events producing individuations (often thought of as 'accidents'). This is a concept that leads in turn into the whole issue of 'the event', of heterogenous assemblies, of processes of actualization of the virtual. 
Clearly it is beyond the scope of this article to pursue the discussions of literature very far, but we might focus on the example of Proust's work, extensively discussed in a number of deleuzian commentaries, including Deleuze (2008). This is the subject of an excellent commentary by Bogue (2008) stressing its relevance for deleuzian pedagogy. Proust's work is often seen as an exploration of subjective memory, but Deleuze wants to argue that it is really a philosophical inquiry into the operation of time itself, including its ability to determine subjective memories and perceptions, but these insights emerge only as Proust develops his own writing technique. This begins 'as an extended apprenticeship in the explication of signs' (Bogue 2008, p. 1), what Bourdieu (1996, p. 201) calls an ethnography, as Proust and/or his narrator (Proust writes in the names of himself and his narrator) begin to investigate the rather exotic subcultures in Paris from which they are initially excluded. These include the elite circles associated with various Parisian salons, and homosexual networks for both men and women.

As his project develops, Proust increasingly displays a 'machinic' writing technique. This moves away from the subjective perspectives of the participants to offer more analysis of the impersonal forces shaping their lives and identities, including historical and social change. More specific techniques include using what might be called 'artificial narratives' based on some nonsubjective device: perhaps the most convenient example concerns a section where Proust/the narrator uses a train journey to structure his recollections of past events, with each station visited serving as a prompt. Deleuze also describes Proust's work as exhibiting a 'body without organs' as he discusses different ways to perceive human faces, for example, and that would have been a useful example for Wyatt and Gale: 'Jonathan' notes that: 'What I have not addressed in this piece, but which I am aware of at this moment, is how... the process of writing to you, now, here, is (or is not?) contributing to...our BwO' (Gale \& Wyatt, 2009, p. 154)

Creative writers seem to have no interest in avant-garde forms in collaborative creative writing, possibly except for a preference for 'freeform' poetry. The artistic avant-garde is important for Deleuze, however, in breaking out of the constraints of ordinary language, and this gives it a political as well as a philosophical significance. We might find demonstrated here a difference in taste, understood by Bourdieu to reflect class position, of 
course: those not in elite groups tend to immediately reject avant-garde work as an affront to common sense, to be greeted with 'confusion, sometimes almost a sort of panic mingled with revolt' (Bourdieu, 1984, p. 33). Perhaps critical philosophy has to be restrained in the interests of social inclusivity in creative writing?

Gale \& Wyatt (2009, p. 16) cite Deleuze \& Parnet (1987, p.1) to say that 'writing is a question of becoming'. However, Deleuze also adds 'there are very few who can call themselves writers' (p. 6). This is because writers with philosophical intents have to learn definite techniques to break with common-sense linguistic and social constraints. They do this by consciously developing technical analysis, 'calculated sobriety in relation to the disparate elements and the parameters' (Deleuze \& Guattari 2004, p. 440), for 'there is no imagination outside of technique' (2004, p. 380).

By contrast, ordinary language draws upon an unreflected 'commonsense', which consists of an image of thought that operates with flawed processes of recognition and repetition (Deleuze 2004, especially chapter 3 ). 'Normal' concepts seem infinitely extendable and self-sufficient and are not open to rigorous self-correction. As with Bourdieu's (2000) notion of the habitus, much ordinary thinking is grounded in unthinking habit. Human beings are particularly unlikely to be aware of these processes and defenceless against them (Deleuze 2004, p. 190). In a phrase which many pedagogues would recognise, common sense involves 'extrapolation from certain facts, particularly insignificant facts... Everyday banality' (2004, p. 171). Guattari makes a similar case based on various Marxist traditions. His argument, in, for example, Guattari (1995) demonstrates the dangerous harmony between common notions of subjectivity and the systems of 'Integrated World Capitalism'.

Deleuze's earlier work argued that far from developing loving, caring relationships with individuals in a warm and supportive academic community, we have to abandon the idea of transparency and good will (including the view that the world itself offers some good will towards our efforts to understand it). Philosophy actually requires an 'individual of ill will' (2004, p. 166), someone who sees subjective presuppositions as prejudices, refuses to go along with convention as 'a wise idiot', and remains critical of current popular thought.

We see some possible problems with ordinary language where 'Ken' 
records his apparently entirely subjective impressions as he walks through Cornwall (UK) (Wyatt et al 2011a). He 'can't help seeing old fishermen everywhere, devout preachers walking from the chapels, and girls in heavy long skirts sorting fish on the quayside'. However, these remarks seem to be fully compatible with the 'romantic gaze' already generated by the tourist industry. Bennett (2000, p. 112) notes that paintings of the Cornish Newlyn School, like Women sharing fish (Gotch 1891), which features women in heavy long skirts sorting fish, but on a beach rather than a quayside, were 'particularly apparent with regard to poster production where the imagery of the fishing communities was widely adopted'. The posters display 'a strong representational if romanticised style in the depiction of simple, dignified working people'.

\section{External Dimensions of Subjectivity in Collaboration 'Between the Two'}

A central claim by Wyatt et al. is that caring and supportive collaborative work, will offer particularly insightful forms of creativity, and this is based on some of Deleuze's comments on his productive collaborations with Guattari, cited in Stivale (2003) and Dosse (2011). Deleuze \& Parnet (1987, p.x) describe the relationship with Guattari: 'What was important for us was less our working together than this strange fact of working between the two of us. We stopped being "author". And these "between-the-twos" referred back to other people'.

Wyatt and Gale also use the term 'between the two' to describe their own work, although they offer only a limited discussion of what they might mean by it and of the circumstances in which it might particularly generate creative writing. For example, the 'other people' referred to in Deleuze's words clearly refer to other writers, of fiction and philosophy, as well as immediate colleagues, which seems to imply that direct contemporaneous correspondence between living contributors is not essential. Deleuze's substantial solo-authored books particularly show the importance of creatively reading the earlier work of others as a prelude to creative writing of one's own.

Forms of collaboration also seem to have varied between Deleuze and his colleagues. Stivale thinks the collaboration with Parnet was initially rather 
like Deleuze's pedagogic technique in lectures, with Deleuze initially discoursing at length and uninterrupted, until Parnet was able to understand his position. Then she was encouraged to ask critical questions about it.

The pattern of collaboration varied even with Guattari. Deleuze \& Guattari (1984) saw Deleuze requiring Guattari to submit written expositions of his favourite concepts, partly to overcome Guattari's writer's block, with Deleuze making subsequent comments. They focused on theoretical issues, especially the critiques of Freud and Lacan that pervade the book. The success of this collaboration lay in their use of 'everything that made them different' (Dosse 2011, pp. 6-7), in their encounters with Lacan for example. There was little dialogue when they did meet: when the other spoke, they listened intently and silently. They took care to try to understand what the other had said and come to some agreement, trying to make each other's ideas work, perhaps to produce academic indirect discourse: it is not clear that any mutual therapy was on the agenda. That produced 'a true "work machine" that made it impossible to know who wrote what precisely' (Dosse 2011, p. 9).

The writing of Deleuze \& Guattari (2004) seemed different, however -both felt more comfortable, and the topics were prompted more on current cultural events and experiences, a choice to move away from a formal philosophical style. The results are both impressive in scope and difficult to follow. However, the possibility arises of yet another nonpersonal contributor to creativity here in the form of the highly productive Parisian elite education and academic habitus (Bourdieu 2000, p.145) that both writers shared and that produces exactly the sort of effortless application of categories and distinctions in erudite discussions that characterise the book. The ferment of critical ideas circulating as a result of the Events of May 1968 must also have played a part.

It is also the case that work conditions were highly conducive. Neither writer was constrained by university conventions: Deleuze seems to have enjoyed almost total autonomy as a distinguished professor. As Wyatt et al well know, that is not the case these days, and Wyatt et al (2017) note the increasing attempts to regulate collaborative academic writing at least at certain early stages in a career. Wyatt and Gale required some astute micropolitical manoeuvring with the aid of their supervisor (Gale et al. 2010) to proceed to present a collaborative thesis, for example. Micropolitics 
seems an ever-present aspect of collaboration, even there is some institutional autonomy: 'In these conditions, as soon as there is this type of multiplicity, there is politics, micropolitics', even with friendly collaborators (Deleuze \& Parnet 1987, p. x).

\section{Guattari and the Cartography of Subjectivity}

Gannon (2006) argued that the autoethnographic self is actually a partial manifestation of subjectivity, embodying only the modern humanist rational self, attempting to know and thus heal itself, as a kind of therapy. This is certainly detectable in the work of Wyatt et al., even at the level of their writing practices, which often seem to begin with moments of what would nowadays be called 'mindfulness' before proceeding to supportive exchanges of emails.

Gannon hints both at other possible forms of subjectivity and at the social and historical processes that install current ones. For Guattari especially, there are pathological forms, for example, like those constrained in the interests of social repression, as we saw. Subjectivity can also end in a narcissistic 'black hole' where everything revolves around personal concerns and personal schema. Examples here include socially isolating behaviour, from the nervous breakdowns and 'crack ups' of writers, artists and philosophers noted in Deleuze (1990) to those institutionalised obsessives and paranoids Guattari encountered in his psychiatric clinic.

All the forms should be seen as contingent variations of underlying processes of subjectification and their complex interconnections. Guattari (2013) aims to 'metamodel' subjectivity, to be able to explain each form as a procedure to make sense. There are personal, social and material processes generating affects of all kinds (not just emotions but perceptions, cognitions, whole points of view) whether we are normally aware of them or not. This explains the dominance of the Unconscious, which is not just the freudian collection of infantile memories which have been repressed, but also the habitual, and the affects from unrecognized material determinants. Personal awareness rarely taps this Unconscious in practice.

For Guattari, there are non-human aspects, 'machines of subjectivation' (Guattari 1995, p. 9), operating in 'a-signifying semiological dimensions' (1995, p. 4), which cannot be understood using conventional semiology. It 
is a mistake to prioritise 'natural language', as does autoethnography, especially if this excludes these and other affects.

(Guattari, 2013) attempts further systematization and clarification, unfortunately at the expense of being almost impenetrably detailed and technical. For Guattari there are four autonomous, heterogeneous but interconnected domains of the Unconscious. Sociologists might immediately recognise the domain of 'incorporeal universes', as including those elements which are normally called cultural, the systems of meanings developed in literature, art, music, philosophy, science and technology which pre-exist particular individuals but still influence them. There are also 'existential territories', the second domain, which include animal territories and natural milieux or neighbourhoods, as well as personal lifeworlds, and these feature pragmatic interests and actions, but still within frameworks of determinants.

In the third domain we encounter autonomous 'flows'. These can be material forces, with direct affects on bodies: Guattari talks of the important psychosomatic affects of bodies on mood and perception rather than any mystical 'agency' of the nonhuman world. If flows are semiotized they can affect the domain of incorporeal universes as well. The fourth domain is that of 'machinic phyla', where a machine is a particular combination of intensive, non-empirical forces and elements and a phylum describes a structured grouping of machines. Phyla can develop autonomous processes of self-positing and self-development, purely machinic possibilities, including 'phase transitions', at an abstract level. The machinic phyla are important because they provide a particular potential for possibilities that are not yet realized, that exist outside current human discourse, that are implicit or immanent. As Guattari (1995, p. 37) puts it: machines have a 'dimension of alterity', a radical potential arising from being able to be joined to (even 'plugged into') other machines in a "'non-human" enunciation'. These potentials can be exploited after phyla transmit affects to human domains via '[non-subjective] tensors of [cognitive] surplus value of the possible' (Guattari 2013, p. 55). We have already seen some of the creative potentials of writing machines, but other examples include military technology or metalworking (a particular contribution of the nomads celebrated in Deleuze \& Guattari 2004). It is also possible to see theoretical or philosophical systems, including sociological ones, as machinic in the same way.

Overall, it would be hard to overestimate the importance of machinic 
developments on contemporary subjectivity, Guattari insists, especially with the advances in communication technology. He saw much potential in the early 'Free Radio' movements in France for example, and it would be interesting to consider the growth of the Web or of social media in this context.

Trying to develop a subjectivity that speaks in its own right constantly risks being dominated by the 'otherness of society' (Guattari 2015, p. 107). The answer is to retain 'maximum communication among different levels [and domains] and, above all, in different meanings'. Guattari calls this 'transversality'. This is necessary to help us become open to a world beyond immediate interests, to develop perspectives, and make enunciations of our own.

It is particularly important to develop 'a decisive re-examination' of institutional truths (Guattari 2015, p. 113), and this would include those of the education system. In staying analytic, we also need to resist the "besotting mythology of "togetherness" (p. 118), perhaps including that close emotional solidarity among autoethnographers. Otherwise, groups also become dependent on consensus (and constant social reinforcement of it in meetings or conferences) and eventually aim only at self preservation to 'magically protect themselves from a non-sense' (p. 119). They become 'subjected groups'. Inevitably, there is an anxiety-producing consequence of groups pursuing transversal communication in that they might have to come to realize they are mistaken. They must pursue transversal and critical inquiries nevertheless, and, in freudian terms, must 'put themselves in the position of having to bring about their own death' (p. 119).

\section{Concluding Thoughts}

Subjectivity is never just a matter of awareness, existing only in our individual consciousnesses. There are clearly external and social elements our past culture, creative techniques including machines of various kinds, the habitus and organizational contexts which affect our efforts.

The emergence of subjective enunciations has to be mapped in each case, and this requires analysis, provided by specialist groups or by individuals. This clearly leaves a role for social science. Neither Deleuze nor Guattari are totally hostile to social science, and indeed draw freely upon ethnographic 
studies, for example. They also tend to rely on cultural marxism. Their critique follows from a denial of the sufficiency of social sciences, which suffer from the 'objective illusion' (DeLanda 2002) that the empirical world is the only reality that exists. The empirical results of social science thus have to be the subject of further 'transcendental' philosophising to develop the task of describing the virtual world which is immanent to the actual one.

Sociological analysis has an important role in tracing some of the links between the domains which are only sketched as arrows in Guattari's diagrams. The links between existential territories and incorporeal universes require transmission mechanisms, for example, which clearly include the education system and the mass media. These transmission mechanisms might produce uneven effects, both accommodation and resistance, and 'micro acts of resistance, refusal and sabotage', even in the university (Roggero 2011, p. 76).

Suitable forms of sociological analysis, at the micro level especially, would have intrinsic merit in checking the abstractions and tendencies to over-generalisation about 'neoliberalism' including those found in autoethnographic work. Instead, they might help inform the development of the micropolitics that Deleuze \& Guattari (2004, Plateau Nine), say is crucial to pursue liberation and transversality in specific concrete institutions and social formations.

\section{References}

Badiou, A. (2000). Deleuze. The clamor of Being. (L. Burchill, Trans.). London: University of Minnesota Press.

Badley, G. (2011). Two nomads writing: a textor's review. Qualitative Inquiry 17(6), (pp. 483-92). doi: 10. 1177/107780041140987

Bennett, A. (2000). The Great Western Railway and the celebration of Englishness. Retrieved from

http://etheses. whiterose.ac.uk/2523/1/DX218855.pdf

Bogue, R. (2008). Search, swim and see: Deleuze's apprenticeship in signs and pedagogy of images. In I. Semetsky (Ed) Nomadic education. Variations on a theme by Deleuze and Guattari (pp: 1-16).

Rotterdam: Sense Publishers.

Bourdieu, P. (2000). Pascalian Meditations. Cambridge: Polity Press. 
Bourdieu, P. (1996). The state nobility, with the collaboration of Monique

De Saint Martin, (L. Clough, Trans.). Cambridge: Polity Press.

Bourdieu, P. (1984) Distinction. A social critique of the judgment of taste.

London: Routledge.

Bourdieu, P, Passeron, J - C, \& Saint Martin, M. (1994). Academic

Discourse. Cambridge: Polity.

DeLanda, M. (2002). Intensive Science and Virtual Philosophy. London:

Continuum.

Deleuze, G. (2008). Proust and signs. (R. Howard, Trans.). London:

Continuum.

Deleuze, G. (2004). Difference and Repetition. (P. Patton, Trans.). London:

Continuum Publishing Group.

Deleuze, G. (1997). Essays critical and clinical. (D. Smith \& M. Greco,

Trans.). Minneapolis: University of Minnesota Press.

Deleuze, G. (1990). The Logic of Sense. (M. Lester, Trans.). New York:

Columbia University Press.

Deleuze, G. \& Guattari, F. (2004). A thousand plateaus. Capitalism and

schizophrenia (B. Massumi, Trans.). London: Continuum.

Deleuze G., \& Guattari, F. (1984). Anti-Oedipus. Capitalism and

Schizophrenia (R. Hurley, M. Seem \& H. Lane. Trans.). London: The Athlone Press.

Deleuze, G. \& Parnet, C. (1987). Dialogues. (H. Tomlinson \& B.

Habberjam. Trans.). London: The Athlone Press.

Denzin, N. (2017). The elephant in the living room, or extending the conversation about the politics of evidence. In N. Denzin \& Y.

Lincoln (Eds.) Handbook of qualitative research. 7th edn. (pp. 83953). Thousand Oaks: Sage Publications.

Dosse, F. (2011). Gilles Deleuze and Felix Guattari: intersecting lives. New York: Columbia University Press.

Gale, K. \& Wyatt, J. (2018). Riding the waves of collaborative-writing-asinquiry: some ontological creative detours. In N. Meier, E. Maslo \&

C. Wegener (Eds) Cultivating Creativity in methodology and research: in praise of detours. London: Palgrave.

Gale, K. \& Wyatt, J. (2017). Working at the wonder: collaborative writing as a method of inquiry. Qualitative Inquiry 23(5), (pp. 355-64). doi: $10.1177 / 1077800416659086$ 
Gale, K., \& Wyatt, J. (2009). Between the two: A nomadic inquiry into collaborative writing and subjectivity. Newcastle upon Tyne:

Cambridge Scholars Publishing.

Gale K., Pelias, R., Russell, R., Spry, T., \& Wyatt, J. (2013). Darkness and Silence: The dis/connection of writing intimacy. International Review of Qualitative Research, 5 (4), (pp. 407-26). doi:

10.1525/irqr.2012.4.407

Gale, K., Speedy, J. \& Wyatt, J. (2010) Gatecrashing the oasis? A joint doctoral dissertation play. Qualitative Inquiry 16 (1), (pp. 21-28). doi: 10.1177/1077800409349758

Gannon, S. (2006). The (Im)Possibilities of Writing the Self: French Poststructural Theory and Autoethnography. Cultural Studies $\Leftrightarrow$ Critical Methodologies, 6 (4), (pp. 474-95). doi:

$10.1177 / 1532708605285734$

Gannon, S. \& Davies, B. (Eds.) (2006). Doing collective biography. Maidenhead: Open University Press.

Guattari, F. (2015). Psychoanalysis and transversality. Texts and interviews 1955-1971. Introduction by Deleuze. (A. Hodges, Trans.). South Pasadena: Semiotext(e).

Guattari, F. (2013). Schizoanalytic Cartographies. (A. Goffey, Trans.). London: Bloomsbury Academic.

Guattari, F. (1995). Chaosmosis: an ethico-aesthetic paradigm. (P. Baines \& J. Pefanis. Trans.). Power Publications: Sydney.

Richardson, L. (2000). Writing. A method of inquiry. In N. Denzin \& Y. Lincoln (Eds.) Handbook of qualitative research. $2^{\text {nd }}$ edn. (pp. 92348). Thousand Oaks: Sage Publications.

Richardson, L. \& St Pierre, EA. (2017). Writing. A method of inquiry. In Denzin and Lincoln The Sage handbook of qualitative research $5^{\text {th }}$ edn. (pp. 818-38). Thousand Oaks: Sage Publications.

Richardson, L. \& St Pierre, E. (2005). Writing: a method of inquiry. In N. Denzin \&.Y. Lincoln. (Eds.). The Sage handbook of qualitative research. $3^{\text {rd }}$ edn. (pp. 959--79). Thousand Oaks: Sage Publications. Roggero, G. (2011) The Production of Living Knowledge: the crisis of the university and the transformation of labour in Europe and North America. (E. Brophy. Trans.). Temple University Press: Philadelphia. 
Short, N., Turner, L \& Short, A. (Eds) (2013). Contemporary British Autoethnography. Rotterdam : Sense.

Stivale, C. (2003). Deleuze/Parnet in "Dialogues": the folds of post identity. The Journal of the Midwest Modern Language Association. 36 (1), (pp. 25-37). doi: 10.23087/1315396

St Pierre, EA. (2016). Deleuze \& Guattari's language for new empirical inquiry. Educational and Philosophical Theory. doi:10.1080/00131857.2016.1151761

St Pierre, E. (2004). Deleuzian concepts for education: the subject undone. Educational Philosophy and Theory, 36(3), (pp. 283-96). doi: 10.1111/j.1469-5812.2004.00068.x

Wyatt, J. \& Gale, K. (2017) Writing to it: creative engagements with writing practice in and with the not yet known in today's academy.

International Journal of Qualitative Studies in Education, July. doi: 10.1080/09518398.2017.1349957

Wyatt, J. \& Gale, K. (2014). Introduction to the special issue on collaborative writing as method of inquiry. Cultural Studies $\Leftrightarrow$ Critical Methodologies 14, 4 (pp: 295-97). doi:10.1177/1532708614530299

Wyatt, J. \& Gale, K. (2011). The textor, the nomads, and a labyrinth: A response to Graham Badley. Qualitative Inquiry 17 (6), (pp. 493-97) doi: 10.1177/1077800411409880

Wyatt, J., Gale, K., Gannon, S. \& Davies, B. (JKSB) (2017). Creating a space in between. Collaborative Inquiries. In N. Denzin \&.Y. Lincoln. (Eds.). The Sage handbook of qualitative research. $7^{\text {th }}$ edn. (pp. 738-56). Thousand Oaks: Sage Publications.

Wyatt, J., Gale, K., Gannon, S., Davies, B., Denzin, N., \& St. Pierre, E. (2014). Deleuze and collaborative writing: Responding to/with "JKSB". Cultural Studies $\Leftrightarrow$ Critical Methodologies, 1-10. doi: $10.1177 / 1532708614530313$

Wyatt, J., Gale, J., Gannon, S. \& Davies, B. (2011a). Deleuze and collaborative writing. An immanent plane of composition. New York: Peter Lang.

Wyatt, J., Gale, K., Russell, L. Pelias, R., \& Spry, T. (2011b). How writing touches: an intimate scholarly collaboration. International Review of Qualitative Research 4 (3) (pp. 253-77). 
48 Harris-Collaborative Writing

David Ernest Harris is Emeritus professor at Plymouth Marjon University, United Kingdom

Contact Address: darrisuk@gmail.com 